\title{
The Effect of Financial Variables on Bank Performance Pre and Post Financial Crisis
}

\author{
Asima Saddique ${ }^{1}$, Mahmood Ahmad ${ }^{1, *}$, Raheel Mumtaz ${ }^{2}$, Muhammad Arif $^{2}$ \\ ${ }^{1}$ Department of Business Administration, Government College University, Faisalabad, Pakistan \\ ${ }^{2}$ Department of Commerce, Government College University, Faisalabad, Pakistan
}

Email address:

asimasaddique@gmail.com (A. Saddique),mahmood_449@yahoo.com (M. Ahmad), raheelmumtaz564@yahoo.com (R. Mumtaz), arif.scholar@yahoo.com (M. Arif)

*Corresponding author

\section{To cite this article:}

Asima Saddique, Mahmood Ahmad, Raheel Mumtaz, Muhammad Arif. The Effect of Financial Variables on Bank Performance Pre and Post Financial Crisis. Journal of Finance and Accounting. Vol. 4, No. 6, 2016, pp. 378-382. doi: 10.11648/j.jfa.20160406.18

Received: December 7, 2016; Accepted: December 19, 2016; Published: January 5, 2017

\begin{abstract}
This study endeavored to find out the effect of financial variables on bank performance pre and post financial crisis of 2008 in Pakistan. Using regression analysis the study revealed that financial crises of 2008 posed a significant influence on the performance of conventional and Islamic banks in Pakistan and pronounced a negative relationship between financial crises and bank performance. The Capital adequacy, assets quality, management quality, liquidity quality, earning quality and bank size posed a negative influence on bank performance during crises while NIM / NNIM showed no effect. Furthermore, Islamic banks affected far less as compared to conventional banks.
\end{abstract}

Keywords: Financial Crisis, Bank Performance, ROA, ROE and NIM/ NNIM

\section{Introduction}

The banking industry is contributing to economic development of the society and well-being of any nation. It has become significant to monitor and command the performance of the banking system and its growth because the banking system is partaking in the evenness of economic development. In topical years banking system commenced a new approach to banking and conquering the extensive enduring expansion of assets and the share value all over the world. Many researchers had examined the bank's financial performance for giving a more clearly imminent side of Islamic banks and its fast growth.

Economic escalation of a country with abundant other aspects is based on the performance of the financial sector in which banking sector is of fanatical magnitude. [1] stated that permanence and development of an economy to an enormous extent based at permanence of banking sector. Banks operates as a mediator between superfluous and shortage of units and smoothen the growth of funds for the industrious purpose, in that way make an addition to the development of an economy. [2] had stated that London had declared the commencement of new British Islamic Market Index and First Islamic Bond (Sakuk) issued by a non-Muslim country, as it's not contented with being "the leading capital of Islamic Finance in the west but mandatory to compete with powerhouses in Muslim world". This situation has elevated a question in the minds of people either Islamic banking system is booming and well organized as compared to the conventional banks. In the past, extensive research have been conducted in examining the causes and factors which differentiate both of the banking streams and helping the banking streams to compete, grow faster and earns more profit.

According to the most recent annual report of the State Bank of Pakistan, till end of June (2013) total deposits of the Islamic banks were Rs.751 Billion with the yearly growth of $29 \%$. And share percentage of total deposits of the Islamic banking system increases in all listed commercial banks from $9.3 \%$ to $10.5 \%$. Total assets of Islamic banking are Rs. 903 Billion with a market share of $9 \%$ of total assets of all commercial banks on 30 June 2013. Latest presented unaudited statistics for quarter 31st December 2013 demonstrated that total assets and deposits of Islamic banking have amplified with Rs. 868 Billion and Rs. 1,014 Billion. 
[3] Investigated the commercial bank's performance in Pakistan and found that with the course of time productivity of the nationalized banks have condensed than public banks. [4] found that commercial banks are playing an important job for the maturity of an economy of Pakistan. Some macroeconomic factors affect them.

This work endeavored to examine the effect of assets quality, management quality, earning quality, liquidity quality, and capital adequacy on bank performance pre and post financial crisis by using panel data. This research is important in line with the effect of the financial crisis on the Pakistan's banking sector either Islamic banking is more effected or conventional banking. To cover the knowledge gap of bank performance related to the effect of the financial crisis on the bank performance of Pakistan's banking sector. Another aim of the study is to identify which parameter has a significant effect on the profitability of the conventional banks and the Islamic banks.

\section{Literature Review}

The comparative study have been conducted by [5] and [6] on Islamic and conventional banking to measuring their recital and found that Islamic banks are operating better than the conventional. For measuring the performance of an organization, many of them used (ROE) returns on equity, (ROI) return on investment, earning per share (EPS). [7] explained that financial ratios explain financial enactment of an organization by analyzing the financial statements as designated by profitability, liquidity, asset utilization, growth ratios and leverage.

Assets of the Islamic banking have reached Rs.1,089 billion while deposits are Rs. 872 billion with the market share $9.8 \%$. At the end of June, the productivity of the Islamic banking business was Rs. 77billion (IBB, SBP, 2014). [8] observe growth and development phases of Islamic banks in Pakistan regarding the development structure like assets, deposits, sources and uses of funds. They also used the performance indicators for calculating the growth and development and concluded that Islamic banking is swiftly growing in the Islamic countries as well as in Pakistan. [9] conducted the comparative study of Islamic and conventional banks for the period of 2000 to 2005 and found that both banking systems were same in profitability, but Islamic banks were less efficient, weak in management and facing high risk as compared to conventional banks.

Research conducted by [10] on Malaysian Islamic and conventional banks during the financial crisis of 2008 and found that both of Islamic banking streams were affected equally, but Islamic banks were good in their liquidity positions because they had more portions of liquid assets as compared to the conventional banks. [11] conducted the study at the effects of financial crises at the bank globalization and found that export leasing was significantly affected. Lending by some foreign banks grew slowly after the financial crises to some extent. [12] examined the effect of financial crises at the European banks by using the risk and profitability analysis approach and found that some banks suffer from bankruptcy and some were in the sensitive situation. Banks are risk sensitive and their profitability hugely affected because of the financial crises. Banks were not in stable conditions their liquidity lowers and risk level increases due to which people started to get back their money from banks. [13] examined the effect of financial crises at the Nigerian banks and found that provision of loan losses increase, capital market's liquidity decreases, exchange rate risk increases and lower growth rate leads to the lower profitability of the banks.

The impact of financial crises on the profitability of banking sector of GCC and found that financial crises do not have significant effect at the profitability of the Islamic banks. In fact size of the banks and equity capital increases the profitability of the Islamic banks and because of increase in the equity capital, expenses of the Islamic bank's decreases and profitability of the Islamic bank's increases [14]. [15] checked the impact of the financial crises at the both banking streams of Islamic and conventional of Qatar's banks and found that Islamic banks management of assets, deposits is better than the conventional banks and Islamic banks were less liquid than the conventional. [10] examined the impact of financial crises on the banks and found that Islamic banks were more stable after financial crises of 2008 while the ratio of risk was also low in the Islamic banks.

They found that most of the European banks were effect by the financial crises. Banks that were more volatile and sensitive to the risk, effects of the financial crises were more severe at those banks. They found that NIM was high from the year 2008 to 2010 because banks were in the state to manage their liabilities, ROE, ROA ratios have fallen sharply during the financial crises for small banks as compared to larger banks. Large banks were in conditions to manage their liabilities and the shortfalls as compared to the small banks that were the reason of the bad performance of the small banks [16]. [2] conducted and compared performance of the Islamic and conventional banks in GCC and MENA country and originate that Islamic banks outpaced conventional banks in provisions of capital adequacy, asset quality, management quality and earnings quality though they had feebler liquidity arrangement as compared to conventional banks. Furthermore, noteworthy statistical distinctions were instituted among Islamic and conventional banks in terms of capital adequacy, management quality, and asset quality. In conclusion, momentous elements of bank profitability are capital adequacy, asset quality, management quality and GDP rate. However, the controlling role of bank category does have a unique control on bank performance in MENA \& GCC region.

The comparative study of Islamic bank performance and Conventional banks pre and post comprehensive financial crisis were conducted by [17], [18], [19], and [20]. The results reveled that performance of Islamic banks in 2008 financial crisis was additional proficient as compared to their complement conventional banks. Islamic Sharia-based mechanism confirmed improved flexibility to negative 
profitability and theory that immensely exaggerated conventional banks. [20] conducted the empirical study of Islamic and conventional banking pre and post financial crisis for the period of 2008 to 2011 and found that Islamic banks were not good in the management quality but marked good capital structure as compared to conventional banks, there were no significant difference for liquidity quality and assets quality of Islamic and conventional banks.

As a result, this escorted to an extraordinary extension of Islamic Banking in an endeavor to alleviate financial system and reinstate investors' assurance in banks as confirmed by [21].

[22] Conducted the empirical study at the stability of the Islamic banks and selected data for the period of 2005 to 2010 and found out that Islamic banks are good in terms of liquidity and the capital adequacy before and after the financial crisis.

\section{Data and Methodology}

Research methodology is a way to solve the research problem systematically. So when we talk about research methodology, we just talk not only research methods, but also takes into account the logic behind the method we use in the course of our research and explains why a certain method is used, or technique and why we are not using the other, so that research results can be evaluated either by the same or by others [23].

\subsection{Population}

Population of this study is Islamic and the conventional banks of Pakistan.

\subsection{Sample Size}

In shaping the sample, researcher selected the banks listed in the stock exchange. Data has been collected from Karachi stock exchange and their respective websites.

\subsection{Capital Adequacy}

Islamic banks are resolute to confine a determined number of customers and retain them by given that the high-quality services and products that are the finest substitutes of the interest based systems products and services for getting their craving profit margins. CA is the measurement of financial potency, besides this is the feasibility of all types of banks in relationships of capital to assets. In our study, capital adequacy will measure with ratio total equity to total assets. In this study CA measured as total equity to total assets such as earlier used by the [2]. Capital adequacy is the capability of the bank that how much reserves they have with them to face the unanticipated losses or bankruptcy. It is the measurement of the organization that for financial stability and the feasibility in a term, how much capital they have for investments and loans.

$$
\text { Capital Adequacy }=\frac{\text { Total Equity }}{\text { Total Assets }}
$$

\subsection{Assets Quality}

When we look at the left side of the balance sheet, it's the assets of the bank. It does include loans; loans define the earning margin and performance of the banks because loans are the foremost cause for banks to earn profits. In this study assets quality will measure by provision for loan losses to total loans as previously used by the [20].

$$
\text { Assets Quality }=\frac{\text { Provision for loan loses }}{\text { Total loans }}
$$

\subsection{Liquidity Quality}

Liquidity is the ability of the bank that how much current assets they have to convene their current liabilities. Liquidity is a crucial matter for banks, in case if they do not have enough current assets with them it may lead banks to the insolvency risk. In this study liquidity, quality will be measured by liquid assets to total.

$$
\text { Liquidity Quality }=\frac{\text { Liquid Assets }}{\text { Total Assets }}
$$

\subsection{Earning Quality}

For measuring the earning quality; cost to revenue ratio is being used in this paper. Its division of operating cost (salaries, wages, fixed, administrative expenses and property) with operating revenue. Basically, it measures the efficiency of banks, lower ratio, and more profitability is. In this study earning quality will be measured by operating cost to operating revenue.

$$
\text { Earning Quality }=\frac{\text { operaing Cost }}{\text { Operating Revenue }}
$$

\subsection{Management Quality}

Management quality means that how much aptitude banks have with them to attract and retain the hefty amount depositors and the investors. How efficiently they are getting trustworthy depositors. In this study management quality will be measured by total loans to total deposits as previously used by [2].

$$
\text { Management Quality }=\frac{\text { Total Loans }}{\text { Total Deposits }}
$$

\subsection{Return on Assets}

Return on assets is profitability indicator. ROA is an ability of the bank that how much ability banks have to generate profit efficiently by using its assets. ROA is simply net income to total assets. ROA is the percentage earn at the total assets.

$$
R O A=\frac{\text { Net Income }}{\text { Total Assets }}
$$

\subsection{Return on Equity}

Return on equity is also a profitability indicator which measures how efficiently banks are using the money, which shareholders have invested and how much they are earning 
profit from that shareholder's money. ROE is net income to total equity. ROE is the percentage earn at the equity.

$$
R O E=\frac{\text { Net Income }}{\text { Total Equity }}
$$

\subsection{Net Interest Margin}

Net interest margin is profitability indicator which is the difference between interest income earned by the loaning/ investing and expenses occurred at the loaning or investment. Actually, this ratio tells either company makes a good decision to make an investment or not. And in the case of Islamic banking, it will be net non-interest margin (NNIM) which is generated from interest-free loans such as musharka, mudarba, ijara and others.

$$
\begin{gathered}
N I M=\frac{\text { Interest income earned from investment or loan- Expenses at the loan or investment }}{\text { Total Assets }} \\
N N I M=\frac{\text { Interest free income earned from investment or loan- Expenses at the loan or investment }}{\text { Total Assets }}
\end{gathered}
$$

\subsection{Size of the Bank}

The size of the bank is the control variable. For conducting the regression analysis in this study will consider the logarithm of total assets, total assets contain the long-term funding and short-term funding. This study is of two streams of banking; Islamic and conventional that's why added a dummy variable bank streams in which Islamic is 1 and conventional is 0 . Like this by assigning the dummies to Islamic and conventional banks, we can find the difference in the performance of both streams of banking.

\section{Empirical Findings}

We used nine regression analyses which are categorized into three main models and applied following tests:

- General and Pure Regression Models

\begin{tabular}{|c|c|c|c|c|c|c|c|c|}
\hline \multirow{2}{*}{$\begin{array}{l}\text { Dependent Variables } \\
\text { Independent Variables }\end{array}$} & \multicolumn{4}{|c|}{ ROA Summary of Random Effect Model } & \multicolumn{4}{|c|}{ ROE Summary of Fixed Effect Model } \\
\hline & (B) & (E) & t-Value & (р) & (及) & (E) & t-Value & (р) \\
\hline$\alpha$ & -3.7953 & 1.7607 & -2.1555 & $0.0323 * *$ & 34.9212 & 14.5616 & 2.3981 & $0.01 * * *$ \\
\hline $\mathrm{CA}$ & -0.0178 & 0.0164 & -1.0855 & 0.2790 & -0.2132 & 0.1313 & -1.6233 & $0.10 *$ \\
\hline AQ & -0.0003 & 0.0207 & -0.0190 & 0.9848 & 0.0509 & 0.1389 & 0.3662 & 0.7146 \\
\hline EQ & -0.3162 & 0.1400 & -2.1646 & $0.0316 * *$ & -1.5136 & 0.6767 & -2.2364 & $0.02 * *$ \\
\hline MQ & 0.0128 & 0.0091 & 1.4006 & 0.1629 & -0.1729 & 0.1510 & -1.1453 & 0.2536 \\
\hline LQ & 0.0681 & 0.0224 & 3.0397 & $0.0027 * * *$ & 0.4508 & 0.2430 & 1.8552 & $0.06^{*}$ \\
\hline $\mathrm{FC}$ & -0.8681 & 0.2564 & -3.3852 & $0.0009 * * *$ & -8.2245 & 2.3342 & -3.5233 & $0.00 * * *$ \\
\hline
\end{tabular}

- Structure Break Analysis

Table 1. Regression Analysis (ROA, ROE).

Table 1 explains that the overall regression model is statistically significant, $F=9.40, p=.0000$. The relationship between return on assets and capital adequacy is negatively insignificant; this shows that $\mathrm{CA}$ is not sharing any variance in the ROA. Assets quality is not sharing variance in ROA and their negative relationship. Earning quality is sharing $31 \%$ variance in ROA and negative relationship shows that as the earning quality decreases, ROA increases because earning quality is operating expenses to operating income as low the value of earning quality is good for the profitability of the banks. Management quality has little bit effect at the ROA during the financial crisis.
While ROE is statistically significant and showing good fitness of model, $\mathrm{F}=14.24, \mathrm{p}=.0000^{* * *}$. CA is sharing variance in ROE but their relationship magnitude is negative this shows that lower the value of the capital adequacy will be lead the banks to face more risk and banks cannot bear the assets losses before and after the financial crisis. AQ is not sharing any variance in ROE pre and post financial crisis. EQ is sharing variance in ROE, but their relationship is negative. Management quality and bank size are not sharing variance in the ROE but liquidity quality is significantly affecting the ROE. Dummy of the financial crisis is showing that financial crisis has significant adverse effect at the ROE.

Table 2. Regression Analysis (NIM, NNIM).

\begin{tabular}{lllll}
\hline Dependent Variables: NIM/NNIM & & & & \\
\hline Independent Variables & Coefficient $(\boldsymbol{\beta})$ & Std. Error $(\boldsymbol{\varepsilon})$ & t-Value & Significance $(\boldsymbol{\rho})$ \\
\hline$\alpha$ & 7.3995 & 3.6475 & 2.0286 & $0.04^{* *}$ \\
CA & 0.0056 & 0.0086 & 0.6486 & 0.51 \\
AQ & 0.0011 & 0.0099 & 0.1167 & 0.90 \\
EQ & 0.0570 & 0.0230 & 2.4714 & $0.01^{* * *}$ \\
MQ & -0.0073 & 0.0338 & -0.2167 & 0.82 \\
LQ & -0.0392 & 0.0288 & -1.3605 & 0.17 \\
Size & -0.4868 & 0.4554 & -1.0691 & 0.286 \\
FC & 0.5246 & 0.1595 & 3.2871 & $0.0012^{* * *}$ \\
\hline
\end{tabular}


Table 2 explains the effects of the financial crisis at bank performance in terms of NIM/NNIM. The results of the cross section random effects regression pre and post financial crisis shows that overall model is statistically significant $\mathrm{f}$-value $=$ $10.93, p=0.00 * * *$. CA and AQ are not sharing any variance in NIM/NNIM. MQ, LQ and BS are also not sharing variance in NIM/NNIM but their relationship magnitude is negative. EQ is sharing variance in NIM/NNIM, Dummy of the financial crisis is affecting the NIM/NNIM positively significantly $(\mathrm{t}$-value $=3.28, \mathrm{p}=0.00 * * *$, coefficient $=0.52)$.

\section{Conclusions and Suggestions}

This study revealed that banking performance was significantly affected by financial crises in 2008. Regression analysis exposed the effect of the financial variables on the bank performance pre and post financial crisis. The Capital adequacy, assets quality, management quality, liquidity quality, earning quality and bank size posed a negative influence on bank performance during crises while NIM / NNIM showed no effect.

This study uses only year-by-year data. Hence, the future researcher can use average values of data in order to evade discretionary accrual effect, which can be made by managers of a firm. The sample size and time period might be increased to enhance the predictability of research.

\section{References}

[1] Siraj, K. and P. S. Pillai, Comparative study on performance of Islamic banks and conventional banks in GCC region. Journal of Applied Finance and Banking, 2012. 2 (3): p. 123.

[2] Al-Gazzar, M. M., The Financial Performance of Islamic vs. Conventional Banks: An Empirical Study on The GCC \& MENA Region. 2014.

[3] Hanif, M. N. and M. F. Arby, Monetary and fiscal policy coordination. 2003.

[4] Abu-Alkheil, A. M., H.-P. Burghof, and W. A. Khan, Islamic Commercial Banking In Europe: A Cross-Country And InterBank Analysis Of Efficiency Performance. The International Business \& Economics Research Journal (Online), 2012. 11 (6): p. 647.

[5] Samad, A. and M. K. Hassan, The performance of Malaysian Islamic bank during 1984-1997: An exploratory study. International Journal of Islamic Financial Services, 1999. 1 (3): p. 1-14.

[6] Safiullah, M., Superiority of conventional banks \& Islamic banks of Bangladesh: A comparative study. International Journal of Economics and Finance, 2010. 2 (3): p. 199.

[7] Gunasekaran, A., et al., Benchmarking performance indicators for banks. Benchmarking: an international journal, 2006. 13 (1/2): p. 147-159.
[8] Alam, P. and C. A. Brown, Disaggregated earnings and the prediction of ROE and stock prices: a case of the banking industry. Review of Accounting and Finance, 2006. 5 (4): p. 443-463.

[9] Olson, D. and T. A. Zoubi, Using accounting ratios to distinguish between Islamic and conventional banks in the GCC region. The International Journal of Accounting, 2008. 43 (1): p. 45-65.

[10] Abdulle, M. Y. and S. H. Kassim, Impact of global financial crisis on the performance of Islamic and conventional banks: empirical evidence from Malaysia. Journal of Islamic Economics, Banking and Finance, 2012. 8 (4): p. 9-20.

[11] Claessens, S. and N. Van Horen, Impact of foreign banks. 2013.

[12] Eken, M. H., et al., The Effects of Global Financial Crisis on The Behaviour of European Banks: A Risk And Profitability Analysis Approach. ACRN Journal of Finance and Risk Perspectives, 2012. 1 (2): p. 17-42.

[13] Dalaien, B. A., Impact of Global Financial Crisis on Banking Sector of India and Jordan. Academic Journal of Economic Studies, 2016. 2 (1): p. 79-95.

[14] Almanaseer, M., The Impact of the Financial Crisis on the Islamic Banks Profitability-Evidence from GCC. International Journal of Financial Research, 2014. 5 (3): p. p176.

[15] Elsiefy, E., Comparative Analysis of Qatari Islamic Banks Performance versus Conventional Banks Before, During and After the Financial Crisis. International journal of business and commerce, 2013. 3 (3): p. 11-41.

[16] Eken, M. H. and S. Kale, Measuring bank branch performance using Data Envelopment Analysis (DEA): The case of Turkish bank branches. African Journal of Business Management, 2011.5 (3): p. 889-901.

[17] Khamis, M. and A. Senhadji, Learning from the PastCountries of the Gulf Cooperation Council confronted the global financial crisis from a position of strength. Finance \& Development, 2010. 47 (1): p. 50.

[18] Hasan, M. M. and J. Dridi, The effects of the global crisis on Islamic and conventional banks: A comparative study. IMF Working Papers, 2010: p. 1-46.

[19] Rashwan, M. H., How did listed Islamic and Traditional Banks Performed: pre and post the 2008 financial crisis? Journal of Applied Finance and Banking, 2012. 2 (2): p. 149.

[20] Merchant, I. P., Empirical study of Islamic banks versus conventional banks of GCC. Global Journal of Management and Business Research, 2012. 12 (20).

[21] Hussein, M., ISLAMIC FINANCE. 2012, Augsburg University.

[22] Tabash, M. I. and R. S. Dhankar, The flow of Islamic finance and economic growth: An empirical evidence of Middle East. Journal of Finance and Accounting, 2014. 2 (1): p. 11-19.

[23] Kothari, C. R., Research methodology: Methods and techniques. 2004: New Age International. 